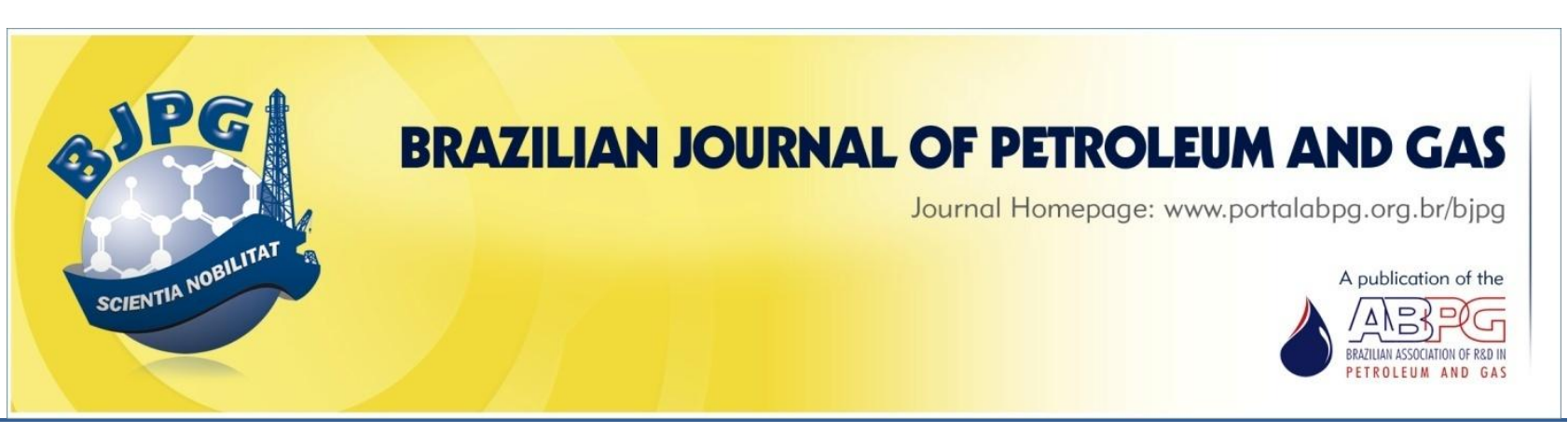

\title{
THE USE OF CCS TECHNOLOGIES IN LARGE SCALE: AN ANALYSIS OF THE BRAZILIAN LEGAL FRAMEWORK
}

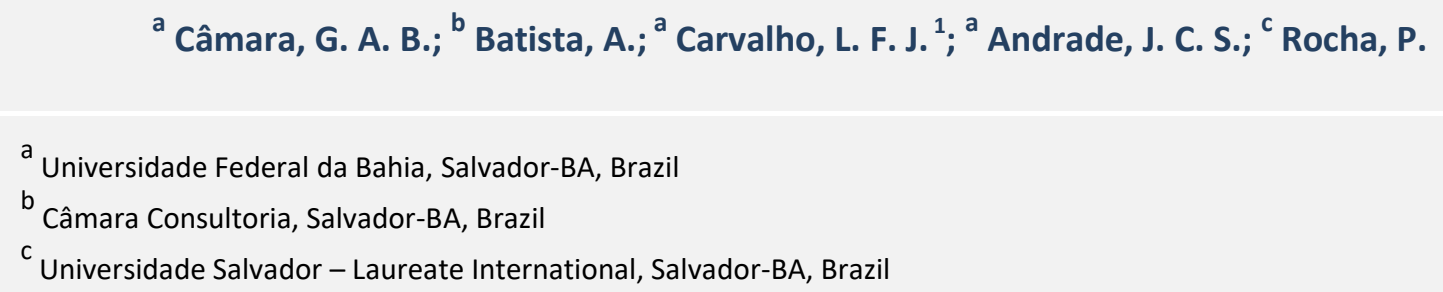

Received: 09.05.2016 / Revised: 23.09.2016 / Accepted: 11.10.2016 / Published on line: 29.12.2016

\begin{abstract}
In the combat of Greenhouse Gases (GHG) emissions, technologies using Carbon Dioxide Capture and Storage (CCS) technologies have shown great results. The structuring of a regulatory framework for the use of CCS technologies is essential to create a trusted environment to civil society and private initiative. International experience points to the development of the regulatory framework for CCS technologies, in particular geological storage of $\mathrm{CO}_{2}$, by means of the regulatory experience of Enhanced Oil Recovery (EOR) technologies. This work has the main objective of identifying the existing legal and infra-legal regulatory documents in force in Brazil which may have some correlation with the CCS technology and its widespread use, in order to identify regulatory gaps and weaknesses for deploying CCS projects in Brazil.
\end{abstract}

\section{KEYWORDS}

CCS; CCS technologies; carbon dioxide; Brazil; legal framework

\footnotetext{
${ }^{1}$ To whom all correspondence should be addressed.

Address: Rua Agnelo de Brito, $n^{\circ}$ 259, Edifício Ondina Empresarial, salas 303 e 304, Federação, Salvador, Bahia, Brasil |

Telefone: +55 (71) 99994-0108 | e-mail: lailajc@gmail.com

doi:10.5419/bjpg2016-0015
} 


\section{INTRODUCTION}

There is a growing demand for an appropriate and sustainable management of natural resources in recent times, especially when it comes to carbon dioxide $\left(\mathrm{CO}_{2}\right)$. As a greenhouse gas (GHG), $\mathrm{CO}_{2}$ attracts attention because of the levels of pollutants in the atmosphere that affect the environment, and also because of its use as a raw material by the oil industry in Enhanced Oil Recovery (EOR).

$\mathrm{CO}_{2}$ is a byproduct of many industrial processes. The major generating sources of $\mathrm{CO}_{2}$ emissions are the petrochemical industry, cement production, fertilizer production, and fossil fuels power plants. Carbon Dioxide Capture and Storage (CCS) is one of the most important processes used in the combat of greenhouse gas emissions. There are many options for $\mathrm{CO}_{2}$ storage, but the focus of this work is the geological storage of $\mathrm{CO}_{2}$.

The geological storage of $\mathrm{CO}_{2}$ is the only climate change mitigation technology currently available that can reduce $\mathrm{CO}_{2}$ emissions from industrial and power generation processes on a significant scale. It is important to understand the differences between CCS and renewable technologies. Although all emission-reduction solutions are needed and important, renewable technologies are not substitutes to CCS (Global CCS Institute, 2015). In a CCS project, the carbon will be stored in an appropriate environment, for example, in oil and natural gas reservoirs. Hydrocarbons have $\mathrm{CO}_{2}$ in their mix of components, and the $\mathrm{CO}_{2}$ is preserved on the pressure and temperature conditions of the reservoir rock without presenting major impacts to the soil.

However, for proper geological storage of $\mathrm{CO}_{2}$, it is crucial to set in place a very well designed regulatory framework, covering both legal and infra-legal issues, to avoid creating conflicts and to establish a trusted environment towards civil society and private initiative. International experience points to the development of the regulatory framework for geological storage of $\mathrm{CO}_{2}$ by means of the regulatory experience of EOR technologies. The United States and Canada are examples of countries that use the EOR technology.

According to the National Enhanced Oil Recovery Initiative (NEORI, 2012), $\mathrm{CO}_{2}$ injection activities to recover oil in the United States began in 1972, in West Texas. Currently, the United States has more than 3,900 miles (Dooley et al., 2006) of ducts to pipelines, and transports about 65 million tons of $\mathrm{CO}_{2}$ annually (Melzer, 2012), producing 281,000 barrels of oil per day (NELT, 2011). The EOR industry has captured, transported, and injected large amounts of $\mathrm{CO}_{2}$ in oil recovery for over four decades without reporting major accidents, serious injuries, and deaths (NEORI, 2012).

It is worth noting the initiative of Cenovus Energy, a Canadian oil company, called Weyburn Project, started in 1998. The project is located in the Canadian province of Saskatchewan. The $\mathrm{CO}_{2}$ used in the project comes from a power plant and is injected into mature oil fields. Even with the initial goal of the EOR, after the recovery of the existing oil, the injection of $\mathrm{CO}_{2}$ will be continued in order to store geologically the $\mathrm{CO}_{2}$ produced by the thermoelectric. For this purpose, it was created by the states a special committee to manage regulatory issues: The Interstate Oil and Gas Compact Commission - IOGCC (Ziliotto, 2009). The University of Regina leads the project (NETL, 2011).

The United States gives great importance to the geological storage of $\mathrm{CO}_{2}$ from EOR projects. In May 2014, US Senator Rockefeller drafted a proposal for amending the Internal Revenue Code of 1986 with the goal of expanding existing tax credits and encouraging the capture, utilization, and sequestration of carbon dioxide. The draft law (S. 2288) is called "Expansion of Carbon Capture through the Advanced Oil Recovery Act of 2014" (USA, 2014).

In 2016, Brazil reiterated the commitment to the implementation of the universal COP21 agreement. All governments involved in the agreement established their own goals and adopted a document called Intended Nationally Determined Contributions (INDC). The Brazilian INDC goals are to reduce greenhouse gases emissions by $37 \%$ until the year 2025 and by $43 \%$ until the year 2030 (Brasil, 2016). These reductions are based on the numbers presented in the year 2005. Nevertheless, Brazil faces an increase in energy consumption and the demand for increasing energy supplies in the upcoming years poses real challenge. In this context, the expansion of power generation by sources other than hydraulic is necessary to guarantee energy security 
in the country. According to the National Power Plan 2030, a document drafted by the Ministry of Mines and Energy, the installation of thermoelectric power plants will be necessary to meet new energy demands. In this scenario, the installation of only $5.000 \mathrm{MW}$ will increase the emissions of $\mathrm{CO}_{2}$ to a number higher than the total emissions from the National Interlinked System in 2005 (Brasil, 2007).

The environmental problems experienced by society today require a more effective way to design the rules for protection and maintenance of natural resources, especially the air. In this context, one must highlight the urgency of preparing environmental legal regulations to ensure the proper management of $\mathrm{CO}_{2}$, providing the most appropriate allocation of gas, improving current environmental conditions, and boosting the $\mathrm{CO}_{2}$ processing industry in Brazil.

The CCS-PI (Carbon Capture and Storage Policy Indicator) of 2015, published by Global CCS Institute, reported that the United Kingdom has set the strongest leadership policies encouraging CCS. Canada and the US also rank highly on that list, showing improvements. China has also implemented a range of positive measures (CCS-PI, 2015).

Currently, the regulation used for $\mathrm{CO}_{2}$ geological storage in Brazil is the result of the analogy of governing rules set for other gases with properties different from the carbon dioxide. These adaptations are precarious and ineffective. Also, as part of CCS technologies come from oil and gas industry, known for being a monopolized industry, it is important to highlight the use of laws to regulate all the chains in the implementation of CCS technologies to avoid a similar situation.

\section{OBJECTIVES AND METHODOLOGY}

This work's main objective is to research and map the existing legal and infra-legal regulatory documents in force in Brazil, which may have some correlation with the CCS technology and its widespread use. This work also seeks to identify regulatory gaps and weaknesses for deploying CCS projects in Brazil. With this information at hand, it will be possible to check the use of existing standards. It will also help define a legal and infra- legal framework that supports the formulation of specific legislation for the activities of CCS technologies in Brazil.

The methodology of this study was based on literature research on the subject and its comparative analysis. In addition, a search in international patent offices was carried out to support the analysis of the stage of applied research in CCS technologies in Brazil. Consequently, a research in the legal and infralegal framework of the Brazilian oil industry was conducted. After the research, the main gaps and needs in the legislation on the use of CCS technology in Brazil and its possible regulation were identified. Finally, an analysis of the situation was performed, leading to the conclusion and recommendations of this work.

\section{THEORETICAL FOUNDATION}

\section{1 $\mathrm{CO}_{2}$ storage technologies in Brazil}

The research activities and development of geological storage of $\mathrm{CO}_{2}$ technologies in Brazil started in the oil industry, specifically at Petrobras. After interviewing experts of Petrobras, we found that some initiatives were being held in Araçás, in the Recôncavo Basin, since 1987, and, according to Lino (2005), $\mathrm{CO}_{2}$ injection tests had started in May 1991 in the Buraçica field, also located in the Recôncavo Basin. In 2009, Petrobras started the injection of $\mathrm{CO}_{2}$ in Miranga, an onshore field in the Recôncavo Basin. This project started as an experience for the injection of $\mathrm{CO}_{2}$ in the pre-salt zone (Maciel, 2010). In 2011, Petrobras started to inject $\mathrm{CO}_{2}$ in Lula field, an offshore field located in the pre-salt zone (Lüders, 2013).

Patents filed by Brazilian entities over the last twenty years in the main world patent offices were researched in the European Patent Office to support the analysis of technologies used for CCS in Brazil. As references for the research, the nine specific codes for CCS technologies in the pollution control item were used. This item is from the IPC Green Inventory, established by the UNFCCC and the World Intellectual Property Organization (WIPO).

Table 1 shows the definition and description of the codes classified by WIPO as part of the CCS technologies. 
Table 1. WIPO codes for CCS technologies.

\begin{tabular}{|c|c|c|}
\hline Definition & Description & $\begin{array}{c}\text { IPC Green Inventory } \\
\text { number }\end{array}$ \\
\hline \multirow{3}{*}{$\begin{array}{l}\text { B01D 53/00 - Separation of gases or } \\
\text { vapors; Recovering vapors of volatile } \\
\text { solvents from gases; Chemical or } \\
\text { biological purification of waste gases, } \\
\text { e.g. engine exhaust gases, smoke, } \\
\text { fumes, flue gases, or aerosols. }\end{array}$} & By absorption & B01D 53/14 \\
\hline & By diffusion & B01D 53/22 \\
\hline & Carbon oxides & B01D 53/62 \\
\hline $\begin{array}{l}\text { Storing fluids in natural or artificial } \\
\text { cavities or chambers in the earth } \\
\text { (modification of mine passages or } \\
\text { chambers for storage purposes, } \\
\text { especially for fluids E21F 17/16). }\end{array}$ & $\begin{array}{c}\text { Devices assisting manual } \\
\text { conveyance of articles over } \\
\text { short distances, i.e. storage } \\
\text { depots, warehouses or } \\
\text { factories }\end{array}$ & B65G 5/00 \\
\hline $\begin{array}{l}\text { C01B 31/00 - Carbon; Compounds } \\
\text { thereof (C01B 21/00, C01B 23/00 take } \\
\text { precedence; percarbonates C01B } \\
\text { 15/10; carbon black C09C 1/48). }\end{array}$ & Carbon dioxide & C01B 31/20 \\
\hline- & $\begin{array}{c}\text { Equipment or details not } \\
\text { covered by groups E21B 15/00- } \\
\text { E21B 40/00 }\end{array}$ & E21B 41/00 \\
\hline $\begin{array}{l}\text { E21B 43/00 - Methods or apparatus } \\
\text { for obtaining oil, gas, water, soluble } \\
\text { or meltable materials, or a slurry of } \\
\text { minerals from wells (applicable only } \\
\text { to water E03B; obtaining oil-bearing } \\
\text { deposits or soluble or meltable } \\
\text { materials by mining techniques E21C } \\
41 / 00 ; \text { pumps F04) }\end{array}$ & $\begin{array}{l}\text { Enhanced recovery methods } \\
\text { for obtaining hydrocarbons } \\
\text { (fracturing E21B 43/26; } \\
\text { obtaining slurry E21B 43/29; } \\
\text { reclamation of contaminated } \\
\text { soil in situB09C) }\end{array}$ & E21B 43/16 \\
\hline $\begin{array}{l}\text { E21F } 17 / 00 \text { - Methods or devices for } \\
\text { use in mines or tunnels, not covered } \\
\text { elsewhere (mine lighting F21, H05B) } \\
{[2]}\end{array}$ & $\begin{array}{l}\text { Modification of mine passages } \\
\text { or chambers for storage } \\
\text { purposes, especially for liquids } \\
\text { or gases (storing fluids in } \\
\text { natural or artificial cavities or } \\
\text { chambers in the earth B65G } \\
5 / 00 \text { ) }\end{array}$ & E21F 17/16 \\
\hline $\begin{array}{l}\text { F25J 3/00 - Processes or apparatus for } \\
\text { separating the constituents of } \\
\text { gaseous mixtures involving the use of } \\
\text { liquefaction or solidification. }\end{array}$ & $\begin{array}{c}\text { By rectification, i.e. by } \\
\text { continuous interchange of heat } \\
\text { and material between a vapor } \\
\text { stream and a liquid stream } \\
\text { (F25J 3/08 takes precedence) }\end{array}$ & F25J 3/02 \\
\hline
\end{tabular}

Figure 1 shows the number of patents filed by Brazilian entities, organized by WIPO codes. In almost ten years, 77 patents were filed.

After more than 20 years of study and the involvement of the private sector and research institutions in Brazil, it is possible to verify that, because of the low number of patents during the period analyzed, the CCS technologies have not been object of applied research in the Country. Thereby, Brazil is in a position of technology buyer.
It is right to say that one of the factors contributing to the non-interest of the industry in general in the topic, not limited to the oil industry, is the lack of regulation for large-scale use of CCS technologies in Brazil. However, for the establishment of a consistent regulatory framework, it is important to discuss some concepts, including the legal and infralegal ones. 


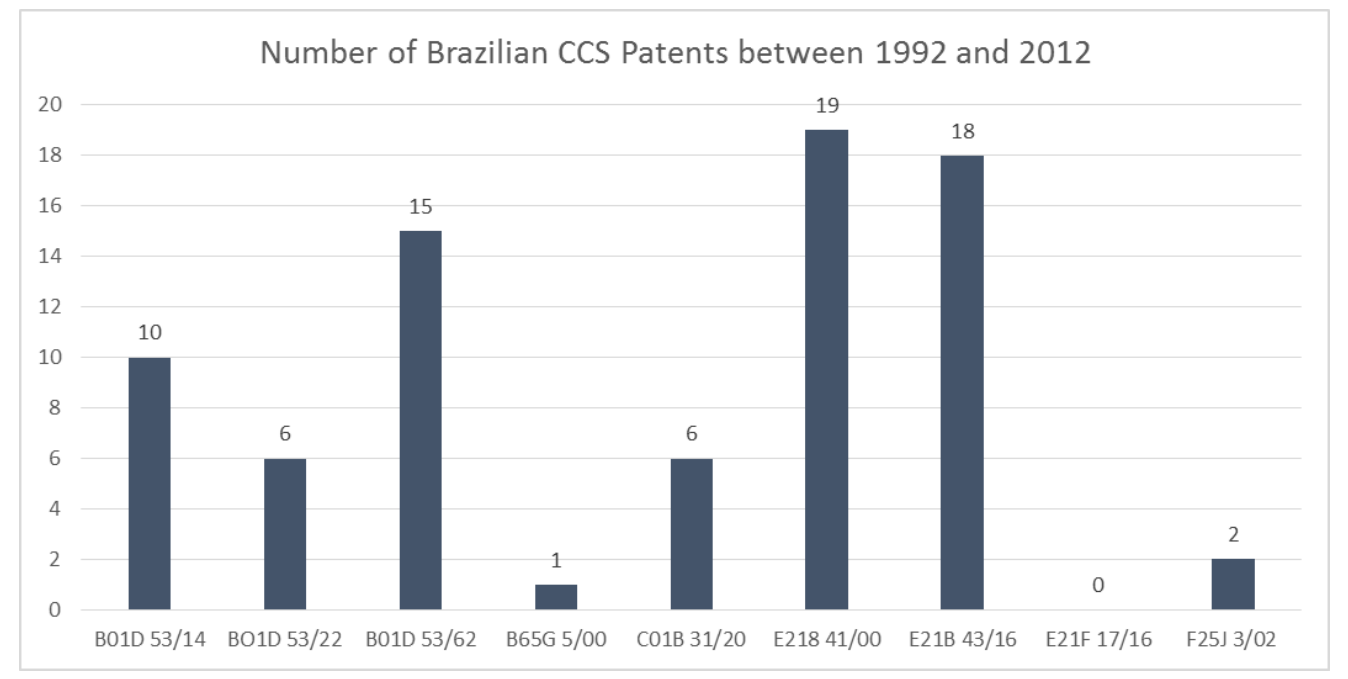

Figure 1. Number of Brazilian CCS patents in ten years.

\section{LEGAL AND INFRALEGAL IN BRAZIL}

\subsection{Legal standards}

The law and legal precepts originate the legal standards. It is the role of the legislative power and the executive power to enforce it with mandatory nature. Therefore, legal standards are all rules which state a model of conduct, assigning rights, powers and obligations imposed by the state.

According to Del Vecchio (1972), law "is the deliberate and conscious legal thought, formulated by special entities, which represent the predominant desire in a society." Thus, the law is the will of the people. In the democratic state, legislators, elected by people through the vote, elaborate the laws.

Concerning the application, the law has a hierarchy. The Federal Constitution is the higher law (Brasil, 1988a); below, there are complementary and ordinary laws, decrees, and administrative rules; at last, other administrative acts. Therefore, the law is a legal instrument that regulates the diverse and complex social relationships, prescribes behavior, and enforces legal sanctions.

\subsection{Infralegal Standards}

Infralegal standards are rules that are considered infra-constitutional laws; i.e., secondary standards that neither have the power to generate rights nor impose obligations. They are: a) Decrees: administrative acts within the competence of leaders of executive power. The decrees have regulatory or enforcement purposes; therefore, the decree details the law, and must not go against law or beyond it;

b) Resolutions: normative administrative acts enacted by higher authorities, but not by the chief of executive power. Resolutions have instructional purposes in their specific competence. They cannot contradict established rules and regulations, but rather explain them. Resolutions can produce external effects;

c) Administrative rules: internal acts originated from leaders for their subordinates. The administrative rules establish general or specific determinations and can initiate investigations or administrative proceedings;

d) Normative instructions: complementary norms. Normative instructions intend to regulate or implement what is stated in the law.

All these definitions are based in the Brazilian concepts of infralegal standards.

\subsection{Analysis of the Brazilian legal and infralegal framework correlated with CCS}

Bearing in mind the US experience with CCS technologies, Marston and Moore (2008) declared, in the publication From EOR to CCS: The Evolving Legal and Regulatory Framework for Carbon 


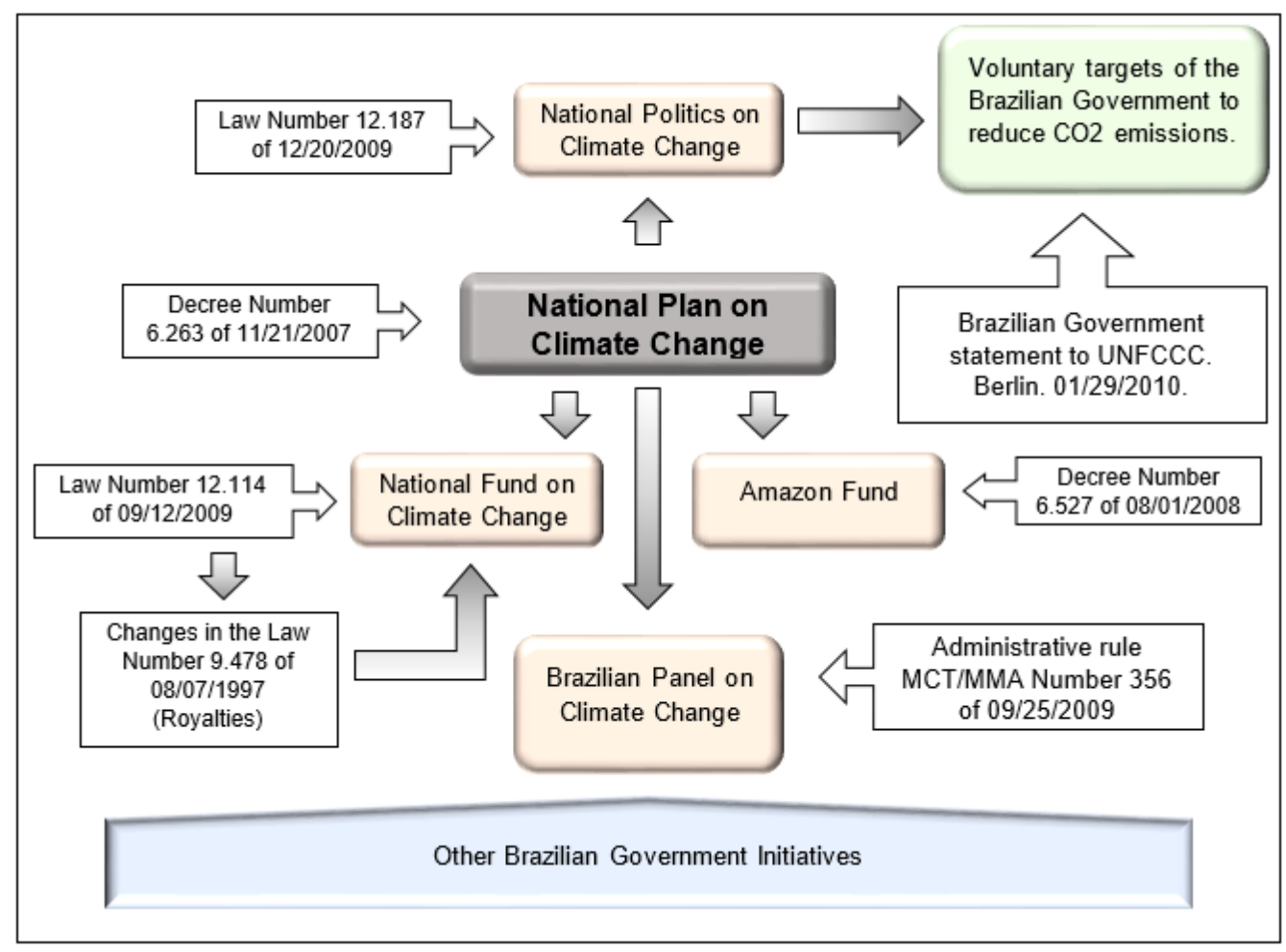

Figure 2. Main Brazilian policies about climate change.

Capture and Storage, that carbon capture and storage has been proposed around the world as a potential key technology for carbon dioxide reduction.

The US oil industry has a long experience in transporting, injecting, and effectively storing $\mathrm{CO}_{2}$ in EOR operations. As a result, there is already a legal and regulatory framework to address many but not all - of the issues that need to be approached if policy makers adopt carbon capture and storage as part of a carbon regulatory regime. A review of the existing structure allows the identification of aspects that seem appropriate to regulate the sale, transport, and injection of $\mathrm{CO}_{2}$, as well as carbon capture with storage purposes, and those which do not have that purpose.

Based on this analysis, Marston and Moore (2008) concluded that the current US legal framework is appropriate from the transactional and provisional standpoint of the EOR to CCS. According to the authors, it is necessary to create policies exclusively focused on injection operations for storage purposes, not on injection for oil recovery purposes.

\subsection{A brief analysis of the Brazilian energy and climate context}

The use of CCS technologies - also applied in sectors such as the petrochemical and cement manufacturing industries - is related closely to the energy sector. Figure 2 shows the main policies and strategies adopted by Brazil in the sector, the main legal bills and respective effective dates. It is important to emphasize that the main sources of $\mathrm{CO}_{2}$ emissions identified by the Ministry of Science and Technology (MCT, 2009) are the land use and forestry, power generation, and oil and gas production and transportation.

The first $\mathrm{CO}_{2}$ injection project in Brazil was done on onshore. The development of exploration and production of oil in large scales from the pre-salt zone will result in a significant increase of $\mathrm{CO}_{2}$ emissions into the atmosphere. In general, hydrocarbon emissions from the pre-salt zone have been between $8 \%$ and $12 \%$ of $\mathrm{CO}_{2}$ (Almeida et al., 2010). The significant presence of $\mathrm{CO}_{2}$ in the presalt hydrocarbon highlights the importance of the CCS technologies in the country. 
Even with a specific regulatory system set for the pre-salt zone, different from the current regulatory framework for the oil and gas sector, nothing was proposed to face the large-scale use of CCS technologies. In short, issues on climate policy were somewhat neglected by the government plan outlined.

Brazil has an energy matrix based on the production of energy through hydroelectric plants. However, the National Energy Plan 2030 (MME $E P E, 2007)$ points out the need for expansion to coal-based, nuclear, biomass, and natural gas power plants. This need for energy will increase by the tons $\mathrm{CO}_{2}$ emissions, thus, reinforcing the need for implementation of CCS technologies.

\subsection{Legal and Infralegal Framework Related to CCS in Brazil}

Looking into the Brazilian laws it is possible to find various legal and infralegal resources that can be used as reference in the creation of a regulatory structure specific to the CCS technologies in the country, especially to transport, injection, and storage of $\mathrm{CO}_{2}$.

Currently, Brazil has its regulatory system grounded in the Federal Constitution. No legal or infralegal proposition may go against what regulated by the Constitution. However, it is noteworthy that if a situation is not regulated in any aspects by the Constitution, infralegal standards can acquire law character to that situation, governing its implementation in the framework established by the standard. Thus, it can be said that, currently, CCS on issues in Brazil are treated based on similar situations, keeping the proportions, due to the lack of specific regulations.

Resolutions and decrees of regulatory agencies or government agencies comply with legal character to deal with issues not addressed in the constitution. These agents have more flexibility to design their regulations, as long as they do not conflict with the propositions of the Constitution. Therefore, there is a fast development of proposals to advance the interests of society.

This study reached the legal and infralegal standards produced by the Brazilian President and some other national agencies. The national agencies are: the National Council of Energy Policy (CNPE); the National Water Resources Council (CNRH); the National Council of Environment (CONAMA); the National Water Agency (ANA); the National Agency of Petroleum, Natural Gas and Biofuels (ANP); the National Land Transportation Agency (ANTT); the Brazilian Association of Technical Standards (ABNT); and the National Institute of Metrology, Quality and Technology (INMETRO). In addition to these national institutions, this study also covered the legal and infra-legal standards produced by the Bahia State government, the State Environment Council (CEPRAM), the State Water Resources Council (CONERH), and the State Agency for Regulation of Public Energy Services, Transport and Communications of Bahia (AGERBA).

Figure 03 shows the types of standards (legal or infralegal) related to CCS technologies that were

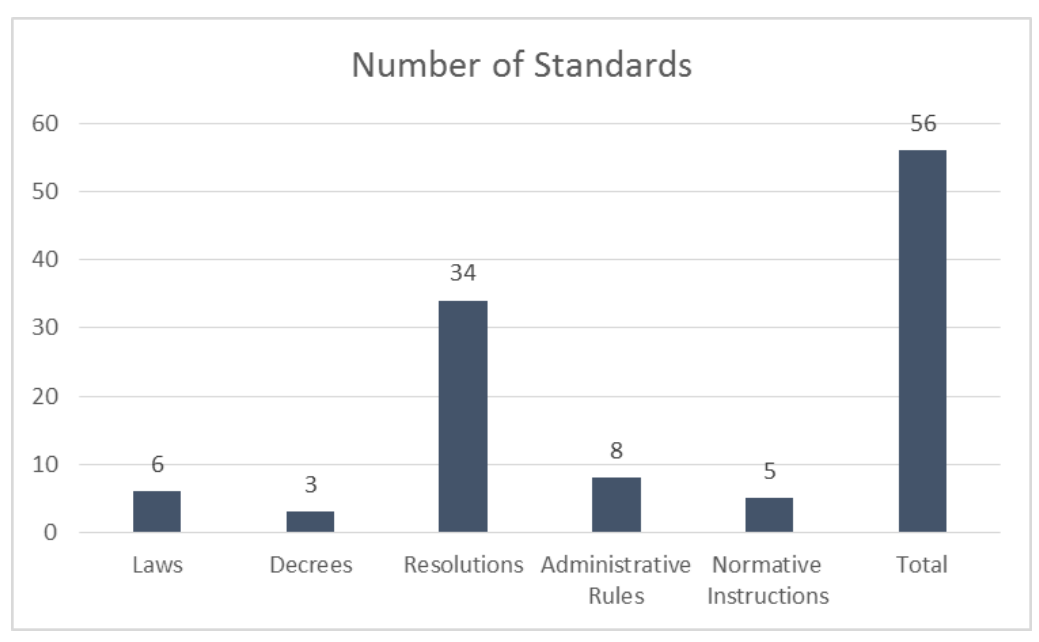

Figure 3. Number of legal and infralegal standards in Brazil. 


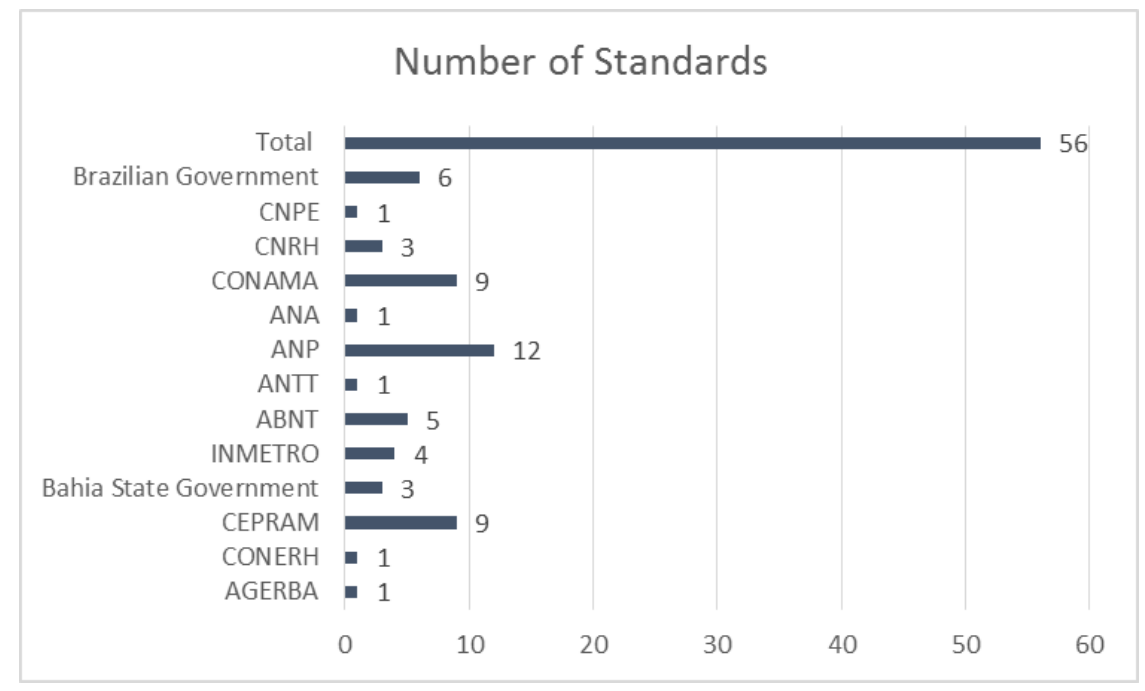

Figure 4. Number of legal and infralegal standards in Brazil by institution.

evidenced. Altogether, 56 legal and infralegal standards were identified. Among those, 34 of them are resolutions. It is worth noting that the research was focused on standards that have direct application to the CCS technologies.

Figure 4 shows the number of standards (legal or infralegal) related to CCS technologies that were evidenced by institution.

It is possible to observe that, at the federal level, CONAMA and ANP are the institutions that have the most regulatory provisions that can be assimilated by CCS technologies. The CONAMA provisions are mainly about conservation and use of land, conservation of water and mineral resources, and preserving biodiversity. The ANP provisions have a technical nature and are directed to the chain of exploration and production of oil and gas, in addition to transport, the EOR technologies, including the abandonment of wells.

\subsection{Main Infralegal Standard focused on EOR, Related to Transport and Geological Storage of $\mathrm{CO}_{2}$}

After reviewing the Brazilian legal and infralegal provisions, it is possible to point out some important issues for the development of a regulatory framework for CCS technologies. One of those issues is that the use of EOR technologies in Brazil has no specific regulation, which is, in accordance with international experience, the most critical issue to structure a regulation for CCS technologies, especially transport and injection, and storage of $\mathrm{CO}_{2}$ in geological reservoirs. Another issue is the lack of clear specifications for the $\mathrm{CO}_{2}$ in the existing regulatory framework, which affects the implementation of pilot projects. Thus, the technical staff of the agencies involved is in charge of decisions regarding approval of projects.

In Brazil, the use of EOR technologies is decided by the field operator, approved by the regulator agency via Development Plan (DP) and, finally, implemented. In this context, there are the technical requirements (particular of each operator) and the DP, which are subject to regulatory approval. To that end, there is ANP Resolution No. 17 of March 18, 2015 that approves the Technical Regulation of the Development Plan. Resolution No. 17 defines the content and establishes procedures regarding the format of the Development Plan for Oil and Natural Gas fields (ANP, 2015).

The Technical Regulation of the Development Plan indicates that if methods of enhanced oil recovery are applied, relevant aspects of the process must be described in the DP, highlighting:

a) Method to be used;

b) Areas of the reservoir to be submitted to improved recovery;

c) Drainage mesh;

d) Use of unconventional wells. 
In addition, if enhanced oil recovery methods are applied, the operator must add information of specific requirements of production lines for the handling and injection of special fluids such as nitrogen, carbon dioxide, water vapor, and other polymers.

In 2015, ANP revoked Administrative Rule № 90 of May 31, 2000 (ANP, 2000) that, before ANP Resolution No. 17 (ANP, 2015), was the infralegal standard that provided the Technical Regulation of the DP. Administrative Rule № 90 also established that if the enhanced recovery methods applied use carbon dioxide, nitrogen or other gases injection, the following information should be submitted:

a) Source of gas for injection;

b) The main characteristics of the treatment system or generation of gas for injection;

c) The main features of the compression system.

The ANP Resolution No. 17 of March 18, 2015 does not require this information in the DP.

One of the important points about $\mathrm{CO}_{2}$ injection in geological reservoirs is the specification of the $\mathrm{CO}_{2}$, not specified in the current Brazilian regulation. The non-compliance with this specification should be considered as critical as the injection of other substances mixed with $\mathrm{CO}_{2}$, which can generate contexts completely different from the planned scenario for a $\mathrm{CO}_{2}$ injection project. Contamination of the injected $\mathrm{CO}_{2}$ can result in significant consequences like the reclassification of the substance to be injected as dangerous; different behavior after injection of the substance compared to the $\mathrm{CO}_{2}$ behavior; damage in the transportation and injection infrastructure designed for $\mathrm{CO}_{2}$, among others.

In the case of $\mathrm{CO}_{2}$ transport, some operators of $\mathrm{CO}_{2}$ pipelines in countries that already perform EOR projects, such as the United States, have established specifications for the $\mathrm{CO}_{2}$ to be transported. Note that this specification is directed to the transport of $\mathrm{CO}_{2}$, but serves as an example for the storage stage, focus of this work. Transport specifications of Canyon Reef project, presented by the IPCC (2005), are as follows:

a) Carbon Dioxide - the product must contain at least ninety-five percent $(95 \%)$ of carbon dioxide; b) Water - the product must not contain free water and must not contain more than 0.489 $\mathrm{m}^{-3}$ in the vapor phase;

c) Acid hydrogen sulfide - the product should not contain more than one thousand five hundred $(1,500)$ parts per million by weight of hydrogen sulfide;

d) Total sulfur - the product should not contain more than one thousand four hundred and fifty $(1,450)$ parts per million by weight of total sulfur;

e) Temperature - the product must not exceed a temperature of $322 \mathrm{~K}$;

f) Nitrogen - the product should not contain more than four percent (4\%) of nitrogen;

g) Hydrocarbons - the product should not contain more than five percent $(5 \%)$ of hydrocarbons and the product dew point (with respect to these hydrocarbons) shall not exceed $244,2 \mathrm{~K}$;

h) Oxygen - the product should not contain more than ten (10) parts per million by weight of oxygen;

i) Glycol - the product should not contain more than $4 \times 10^{-5} \mathrm{~L} \mathrm{~m}^{-3}$ glycol and, in anytime, this glycol should be present in liquid pressure conditions and temperature of the gas pipeline.

In Brazil, there is no similar control of gas transport containing specifications of $\mathrm{CO}_{2}$ to be transported. The existing regulation, the Federal Decree 96044 of May 18, 1988, focuses on the transport of dangerous goods. The decree covers, in general, the transportation of dangerous goods and other legal instruments, such as resolutions and instructions from the National Land Transportation Agency (ANTT) (Brasil, 1988b). As described in the Brazilian legal instruments for the transport of $\mathrm{CO}_{2}$, and following the guidelines of the United Nations (UN), the $\mathrm{CO}_{2}$ is classified both in gaseous or liquid phase, as a non-flammable gas, non-toxic, however asphyxiating and oxidant.

With regard to the environment, national laws and environmental regulations that have direct or indirect relation to the injection of $\mathrm{CO}_{2}$ in geological reservoirs are basically the Federal Laws; the resolutions set by CONAMA; the specific environmental regulations for the oil industry- 
ANP; and the one focused on the use and conservation of water resources of the ANA and CNRH. In this context, we highlight the environmental licensing with the identification of needs to be taken by the operator of a $\mathrm{CO}_{2}$ injection project.

Still on environmental issues, in a state level, especially in the state of Bahia, there is Decree $11 / 235$ of October 10, 2008, in which issues relating to the geological storage of substances can be identified. However, the focus is on the pollution of the soil and subsoil and, for a direct application in a $\mathrm{CO}_{2}$ injection project, it would be necessary to classify $\mathrm{CO}_{2}$ as a pollutant.

\section{FINAL CONSIDERATIONS}

It is possible to check the existence of few regulatory aspects in the current Brazilian regulatory framework for the oil industry and the environment that meet the requirements of the CCS technologies. This lack in laws is completely understandable and predictable because CCS technologies are recent and current laws and regulations do not provide for the use of such technologies.

The need for drafting legal and infralegal instruments such as laws, decrees, regulations, among others, is of utmost importance in establishing an enabling environment regulations for private sector investment and consequently expanding the use of CCS technologies.

The expected Brazilian economic and industrial growth suggests that, in the coming years, $\mathrm{CO}_{2}$ emissions in the country will increase. The activities in the oil industry, especially activities related to exploration in the pre-salt zone, and the increasing demand for energy, will be the major concerns involving the emissions of $\mathrm{CO}_{2}$ in Brazil.

International experience points to the use of the regulatory framework of the oil industry, in particular for EOR technologies, which should serve as a parameter for the development of the regulatory framework of CCS technologies in Brazil. However, the absence of parameters weakens the existing structure for its use in CCS projects, in particular geological storage of $\mathrm{CO}_{2}$.
It is possible to point out that Brazil has a great potential for geological storage of $\mathrm{CO}_{2}$ based on the existence of mature oil basins or basins in declined production, such as the Recôncavo Basin, which are favorable for large-scale use of CCS technology. Nonetheless, the actual regulatory framework is unfavorable for the development of CCS projects. Therefore, to implement a large-scale use of CCS technologies in the country, it is necessary that the government regulates the $\mathrm{CO}_{2}$ chain from the sources to the sinks. This way, it is necessary a cooperative work to define the responsibilities of each level in the chain.

\section{ACKNOWLEDGEMENTS}

Federal University of Bahia - UFBA, (Industrial Engineering Program - PEI), UNIFACS/Laureate International Universities and The Brazilian Federal Agency for Support and Evaluation of Graduate Education - CAPES.

\section{REFERENCES}

Almeida, A. S.; Rocha, P. S.; Lima, S. T.; Pinto, A. C. C.; Branco, C. C. M.; Salomão, M. C. A study on the potential for CCGS in the Pre-salt cluster of Santos Basin: the Tupi pilot application. Rio Oil \& Gas Expo and Conference, Instituto Brasileiro de Petróleo, Gás e Biocombustíveis - IBP. Rio de Janeiro, 2010.

ANP - Agência Nacional do Petróleo, Gás Natural e Biocombustíveis. Resolução ANP № 17 de 18.3.2015 - DOU 20.3.2015. Available at: <http://nxt.anp.gov.br/NXT/gateway.dll/leg/resolu coes_anp/2015/mar\%C3\%A7o/ranp\%2017\%20-

$\% 202015 . x m l$ ?fn=document-

frameset.htm\$f=templates\$3.0>. Accessed on: 04 March 2016. (In Portuguese)

ANP - Agência Nacional do Petróleo, Gás Natural e Biocombustíveis. Portaria ANP № 90, de 31.5.2000 - DOU 1.6.2000. Available at: <http://nxt.anp.gov.br/NXT/gateway.dll/leg/folder _portarias_anp/portarias_anp_tec/2000/maio/pan p\%2090\%20-\%202000.xml>. Accessed on: 04 March 2016. (In Portuguese) 
Brasil. Casa Civil, 1988b. Decreto 96044/1988 Regulamento para o Transporte Rodoviário de Produtos Perigosos. Available at: <http://www.planalto.gov.br/ccivil_03/decreto/antigo s/d96044.htm>. Accessed on: 04 March 2016. (In Portuguese)

Brasil. Ministério de Minas e Energia, 2007. Plano Nacional de Energia 2030. Brasília. Available at: <http://www.epe.gov.br/PNE/20080111_1.pdf $>$ Accessed on: 20 September 2016. (In Portuguese)

Brasil. Ministério de Minas e Energia, 2016. Available at: <http://www.mma.gov.br/clima/convencao-dasnacoes-unidas/acordo-de-paris >. Accessed on: 20 September 2016. (In Portuguese)

Brasil. Presidência da República, 1988. Constituição da República Federativa do Brasil de 1988, 1988a. Available at: http://www.planalto.gov.br/ccivil_03/constituicao/ constituicao.htm. Accessed on: 04 March 2016. (In Portuguese)

CCS-PI, Global CCS Institute, 2015. The Global Status of CCS. Available at: $<$ http://hub.globalccsinstitute.com/sites/default/fil es/publications/196843/global-status-ccs-2015summary.pdf $>$. Accessed on: 20.09.16.

Del Vecchio, G. Lições de Filosofia do Direito. $4^{\text {th }}$ Edition. Coimbra: Arménio Amado,1972. (In Portuguese)

Dooley, J. J.; Dahowski, R. T.; Davidson, C. L.; Wise, M. A.; Gupta, N.; Kim, S. H.; Malone, E. L. Carbon dioxide capture and geologic storage: $\mathrm{A}$ core element of a global energy technology strategy to address climate change. Battelle Memorial Institute, U.S, 2006. Available at: $<$ http://www.globalchange.umd.edu/data/gtsp/wo rkshops/2006/ccs_report.pdf>. Accessed on: 04 March 2016.

Global CCS Institute. Global CCS Institute CCS Legal and Regulatory Indicator: A global assessment of national legal and regulatory regimes for carbon capture and storage, 2015. Available at: <https://hub.globalccsinstitute.com/sites/default/f iles/publications/196443/global-ccs-institute-ccslegal-regulatory-indicator.pdf>. Accessed on: 04 March 2016.
IPCC. IPCC special report on carbon dioxide capture and storage. Intergovernmental Panel on Climate Change, Cambridge University Press, Cambridge, 2005. Available at: $<$ https://www.ipcc.ch/pdf/specialreports/srccs/srccs_wholereport.pdf $>$. Accessed on: 04 March 2016.

Lino, U. R. A. Case History of Breaking a Paradigm: Improvement of an Immiscible GasInjection Project in Buracica Field by Water Injection at the Gas/Oil Contact. SPE Latin American and Caribbean Petroleum Engineering Conference. Rio de Janeiro, 2005. Available at: $<$ https://www.onepetro.org/conference-paper/SPE94978-

MS? sort $=\&$ start $=0 \& q=$ Case + History + of + Breaking $+a+$ Par adigm\%3A+Improvement+of+an+Immiscible+GasInjection+Project+in+Buracica+Field+by+Water+Injectio n+at+the+Gas\%2FOil+Contac\&from_year=\&peer_review ed=\&published_between=\&fromSearchResults=true\&to _year=\&rows=10\#>. Accessed on: 04 March 2016.

Lüders, G. Petrobras inicia nova técnica para recuperar pré-sal". Exame.com, 08 April 2013. Available at:

<http://exame.abril.com.br/negocios/noticias/petr obras-inicia-nova-tecnica-para-recuperar-pre-sal>. (In Portuguese)

Maciel, F. Mais quinze anos de produção: Petrobras inicia injeção de $\mathrm{CO}_{2}$ em Miranga, no Recôncavo, que ampliará volume de óleo e será teste para o pré-sal. Brasil Energia, 02 February 2010. Available at:

$<$ http://brasilenergiaog.editorabrasilenergia.com/n ews/2010/02/403357.html>. (In Portuguese)

Marston, P. M.; Moore, P.A. From EOR to CCS: The Evolving Legal and Regulatory Framework for Carbon Capture and Storage, 2008. Available at: $<$ http://www.marstonlaw.com/index_files/From\%2 0EOR\%20to\%20CCS.pdf>. Accessed on: 04 March 2016.

MCT. Inventário Brasileiro das Emissões e Remoções Antrópicas de Gases de Efeito Estufa Informações Gerais e Valores Preliminares. Brasília: Ministério de Ciência e Tecnologia, p. 19. Issue Date: 30 November 2009. (In Portuguese)

Melzer, L. S. Carbon Dioxide Enhanced Oil Recovery $\left(\mathrm{CO}_{2}\right.$ EOR): Factors Involved in Adding Carbon Capture, Utilization and Storage (CCUS) to Enhanced Oil Recovery, 2012. Available at: <http://neori.org/Melzer_CO2EOR_CCUS_Feb2012 .pdf> Accessed on: 04 March 2016. 
MME - EPE. Plano Nacional de Energia 2030. Brasília: Ministério de Minas e Energia, Empresa de Pesquisa Energética, p. 324, 2007. Available at: <http://www.epe.gov.br/PNE/20080111_1.pdf> Accessed on: 04 March 2016. (In Portuguese)

NEORI. Carbon Dioxide Enhanced Oil Recovery: A Critical Domestic Energy, Economic, and Environmental Opportunity. National Enhanced Oil Recovery Initiative. U.S, 2012. Available at: <http://www.neori.org/NEORI_Report.pdf>.

Accessed on: 04 March 2016.

NETL. Improving Domestic Energy Security and Lowering $\mathrm{CO}_{2}$ Emissions with 'Next Generation' $\mathrm{CO}_{2}$-Enhanced Oil Recovery ( $\mathrm{CO}_{2}$-EOR) National Energy Technology Laboratory, U.S. Department of Energy. USA: Issue Date: 20 June 2011. Available at: <http://www.netl.doe.gov/energyanalyses/pubs/storing\%20co2\%20w\%20eor_final.p df>. Accessed on: 04 March 2016.
USA - Senate of The United States. Expanding Carbon Capture through Enhanced Oil Recovery Act of 2014. Available at: <https://www.congress.gov/bill/113thcongress/senate-bill/2288> Accessed on: 04 March 2016.

Ziliotto, M. A. B. Mudanças Climáticas, Sequestro e Mercado de Carbono no Brasil. Curitiba: 2009. (In Portuguese) 